\title{
The Single-Headed Fourth Branch: Judge Kavanaugh, PHH Corp. v. Consumer Financial Protection Bureau, and the Future of the Social Security Administration
}

\author{
Joy Merklen*
}

“You're fired."-Donald J. Trump ${ }^{1}$

\section{INTRODUCTION}

Even a cursory study of Justice Brett Kavanaugh shows he likes two things: beer ${ }^{2}$ and the unitary executive theory. ${ }^{3}$ From the start of his time on the D.C. Circuit, then-Judge ${ }^{4}$ Kavanaugh focused on presidential control over the administrative state. In just his second year on the bench, Judge Kavanaugh penned a passionate dissent in Free Enterprise Fund v. Public Company Accounting Oversight Board. ${ }^{5}$ There, Judge

\footnotetext{
* J.D. Candidate, 2020, University of Kansas School of Law; B.A., 2016, Sociology, University of California, Berkeley. I would like to thank Professor Richard Levy and the members of the Kansas Law Review for their thoughtful review of this Comment and Neil Dryden for invaluable assistance, editorial and otherwise.
}

1. The Apprentice: Meet the Billionaire (NBC television broadcast Jan. 8, 2004).

2. See Kavanaugh Hearing: Transcript, WASH. Post (Sept. 27, 2018, 4:56 PM), https://www.washingtonpost.com/news/national/wp/2018/09/27/kavanaugh-hearing-transcript/ [https ://perma.cc/L3L6-PWMZ] ("I like beer. I like beer."). On day five of the Senate Judiciary Committee Hearing on Judge Kavanaugh's nomination for Associate Justice of the Supreme Court, Judge Kavanaugh, in discussing Dr. Christine Blasey Ford's sexual assault allegations, uttered the word "beer" twenty-nine times. See id.

3. See, e.g., Brett M. Kavanaugh, Separation of Powers During the Forty-Fourth Presidency and Beyond, 93 MinN. L. REV. 1454, 1459-62, 1484 (2009) (endorsing the unitary executive theory by announcing a policy preference for a strong executive functioning free from "unnecessary distractions," including the investigation, indictment, or prosecution of a sitting President); Brett M. Kavanaugh, The President and the Independent Counsel, 86 GEO. L.J. 2133, 2137 (1998) (using the unitary executive theory to argue that a President should be immune from prosecution while in office). See also Nomination of the Honorable Brett M. Kavanaugh to Be an Associate Justice of the Supreme Court of the United States (Day 4): Hearing Before the S. Comm. on the Judiciary, 115th Cong. 4 (Sept. 7, 2018) (testimony of Professor Peter M. Shane) ("Judge Kavanaugh's record on issues of presidential authority demonstrates that he has become an activist .... Judge Kavanaugh is not just an enthusiast for presidential power; he is a campaigner.").

4. Because this Comment focuses on Justice Kavanaugh's opinions during his time on the D.C. Circuit, it will predominantly refer to Justice Kavanaugh as Judge Kavanaugh.

5. See 537 F.3d 667, 685-715 (D.C. Cir. 2008) (Kavanaugh, J., dissenting), aff'd in part, rev'd in part, 561 U.S. 477 (2010). 
Kavanaugh argued that two layers of protection for executive officers from removal at will by the President violates separation of powers by unduly diluting the President's control over the executive branch. ${ }^{6}$ When the case reached the Supreme Court two years later, the 5-4 conservative majority largely agreed with Judge Kavanaugh's dissent. ${ }^{7}$ Free Enterprise Fund buttressed the unitary executive theory to expand presidential control of agencies and chip away at the constitutionality of independent agencies. ${ }^{8}$

On July 9, 2018, President Trump nominated Judge Kavanaugh to fill Justice Kennedy's seat on the United States Supreme Court. ${ }^{9}$ In his Senate questionnaire submitted to the Judiciary Committee in advance of his confirmation hearing, Judge Kavanaugh selected his dissent in Free Enterprise Fund as his most significant opinion. ${ }^{10}$ Judge Kavanaugh also listed his dissent in PHH Corp. v. Consumer Financial Protection Bureau, ${ }^{11}$ a more recent opinion that addresses the constitutionality of independent agencies with a single-head structure, as a "significant constitutional opinion[]" he has authored. ${ }^{12}$ Indeed, he is correct. Judge Kavanaugh's $P H H$ dissent, if followed by the Supreme Court, will

6. Id. at 686 ("[T] $]$ he President is two levels of for-cause removal away from [Public Company Accounting Oversight Board (PCAOB)] members, a previously unheard-of restriction on and attenuation of the President's authority over executive officers. This structure effectively eliminates any Presidential power to control the PCAOB ....").

7. See Free Enter. Fund v. Pub. Co. Accounting Oversight Bd., 561 U.S. 477, 492 (2010) (holding "dual for-cause limitations" on removal "contravene the Constitution's separation of powers").

8. The Free Enterprise majority insisted that its decision was unremarkable. See id. at 50708. But that assertion is hard to square with the majority opinion's broad language appealing to the unitary executive theory, which opened the discussion of the President's removal power by quoting Article II's Vesting Clause and James Madison's statement in the First Congress that "if any power whatsoever is in its nature Executive, it is the power of appointing, overseeing, and controlling those who execute the laws." Id. at 492 (citation omitted). The Court stressed that "a single President [is] responsible for the actions of the Executive Branch," $i d$. at 497 (quoting Clinton v. Jones, 520 U.S. 681, 712-13 (1997) (Breyer, J., concurring)), and that measures to dilute the President's control over the executive branch "subvert[] the President's ability to ensure that the laws are faithfully executed-as well as the public's ability to pass judgment on [their] efforts," $i d$. at 498. In dissent, Justice Breyer noted that he "s[aw] no way to avoid sweeping hundreds, perhaps thousands of high-level Government officials within the scope of the Court's holding, putting their job security and their administrative actions and decisions constitutionally at risk." Id. at 538-41 (Breyer, J., dissenting).

9. Mark Landler \& Maggie Haberman, Brett Kavanaugh Is Trump's Pick for Supreme Court, N.Y. TiMES (July 9, 2018), https://www.nytimes.com/2018/07/09/us/politics/brett-kavanaughsupreme-court.html [https://perma.cc/WKY2-LFTZ].

10. Questionnaire for Nominee to the Supreme Court submitted by Brett M. Kavanaugh to the United States Senate Committee on the Judiciary 43 (2018), https://www.judiciary.senate.gov/imo $/$ media/doc/Brett\%20M.\%20Kavanaugh\%20SJQ\%20(PUBLIC).pdf [https://perma.cc/3NKL-X2ZG] [hereinafter Senate Questionnaire].

11. 881 F.3d 75 (D.C. Cir. 2018) (en banc).

12. Senate Questionnaire, supra note 10, at 63. 
reshape the law concerning presidential control over the administrative state and raise serious questions about the constitutionality of important independent agencies, ${ }^{13}$ including, perhaps most directly, the Social Security Administration (SSA). ${ }^{14}$

In $P H H$, Judge Kavanaugh argued that the Consumer Financial Protection Bureau (CFPB) Director's for-cause removal protection violates the Constitution's separation of powers by vesting "substantial executive authority" in a single individual unaccountable to the President, rather than a multimember body. ${ }^{15}$ Judge Kavanaugh characterized $\mathrm{PHH}$ as a "much starker case of unconstitutionality than Free Enterprise Fund." 16 Although $P H H$ will not make its way up to the Supreme Court (neither party petitioned for certiorari),${ }^{17}$ the Supreme Court agreed to hear the constitutional challenge in another case. ${ }^{18}$ Judge Kavanaugh's dissent also remains alive in the lower courts. ${ }^{19}$ Several

13. Independent agencies are typically defined by for-cause removal restrictions. See Jacob E. Gersen, Designing Agencies, in Research Handbook on Public Choice and Public Law 333, 347 (Daniel A. Farber \& Anne Joseph O’Connell eds., 2010); Elena Kagan, Presidential Administration, 114 HARV. L. REV. 2245, 2376 (2001) (stating that the President's removal power is "the core legal difference" between independent and executive agencies); Cass R. Sunstein, Paradoxes of the Regulatory State, 57 U. CHI. L. REV. 407, 426 (1990) ("An agency is independent if Congress has provided that its members can be discharged by the President only for specified causes.”). But see Kirti Datla \& Richard L. Revesz, Deconstructing Independent Agencies (and Executive Agencies), 98 CORNELL L. REV. 769, 776 (2013) (challenging the consensus view and arguing that "not all agencies considered independent possess such a clause").

14. See infra Section II.C.

15. PHH, $881 \mathrm{~F} .3 \mathrm{~d}$ at 165 (Kavanaugh, J., dissenting) ("[T]he heads of executive agencies are accountable to and checked by the President; and the heads of independent agencies, although not accountable to or checked by the President, are at least accountable to and checked by their fellow commissioners or board members. No independent agency exercising substantial executive authority has ever been headed by a single person. Until now.").

16. Id. at 190 .

17. Neither party petitioned for certiorari presumably because, while the en banc court upheld the constitutionality of the CFPB's design, it vacated the CFPB's $\$ 109$ million fine against the mortgage company. See id. at 83-84 (majority opinion).

18. See Consumer Fin. Prot. Bureau v. Seila Law LLC, 140 S. Ct. 427 (Oct. 18, 2019) (No. 19 7) (mem.).

19. See, e.g., Collins v. Mnuchin, 896 F.3d 640, 659-72 (5th Cir. 2018) (relying heavily on Judge Kavanaugh's dissent in $\mathrm{PHH}$ in finding the single-head structure of the Federal Housing Finance Agency (FHFA) unconstitutional), aff'd in part, rev'd in part en banc, 938 F.3d 553 (5th Cir. 2019) (reinstating the panel's finding that the FHFA's single-head structure is unconstitutional), petition for cert. filed, No. 19-422 (U.S. Sept. 25, 2019); Consumer Fin. Prot. Bureau v. RD Legal Funding, LLC, 332 F. Supp. 3d 729, 784 (S.D.N.Y. 2018) (expressly adopting Judge Kavanaugh's $\mathrm{PHH}$ dissent in finding the CFPB's structure unconstitutional but rejecting Judge Kavanaugh's severance remedy), appeal docketed, No. 18-2743 (2d Cir. Sept. 17, 2018). But see Bhatti v. Fed. Hous. Fin. Agency, 332 F. Supp. 3d 1206, 1215-17 (D. Minn. 2018) (noting in dicta that even if the plaintiffs had standing to challenge the FHFA's structure, their claim would fail on the merits, agreeing with the en banc D.C. Circuit's "thorough opinion" in $P H H$ and finding Judge Kavanaugh's panel opinion "unpersuasive"), appeal docketed, No. 18-2506 (8th Cir. July 16, 2018); Consumer Fin. Prot. Bureau v. Think Fin., LLC, No. CV-17-127-GF-BMM, 2018 WL 3707911, at*2 (D. 
cases raise similar constitutional challenges, including an appeal in the Second Circuit from a district court decision expressly adopting Judge Kavanaugh's $\mathrm{PHH}$ dissent. ${ }^{20}$ Further, the Fifth Circuit in Collins v. Mnuchin applied Judge Kavanaugh's approach to invalidate the structure of the Federal Housing Financial Agency (FHFA). ${ }^{21}$ Unsurprisingly, Seila Law LLC's petition for a writ of certiorari in Seila Law LLC v. Consumer Financial Protection Bureau refers extensively to Judge Kavanaugh's $P H H$ dissenting opinion. ${ }^{22}$

Judge Kavanaugh's approach reflects an inherent distrust, widely shared among conservatives, of the modern administrative state. His dissent in $\mathrm{PHH}$ characterizes independent agencies as comprising a "headless fourth branch of the U.S. Government" that "pose[s] a significant threat to individual liberty and to the constitutional system of separation of powers and checks and balances." 23 This characterization of independent agencies resurrects the post-New Deal critique that helped fuel the adoption of the Administrative Procedure Act, ${ }^{24}$ and in so doing, indicates a desire to reopen the seemingly settled debate about the constitutionality of the modern administrative state. Given that recent Supreme Court cases have already applied the unitary executive theory to expand presidential control and that several individual Justices have questioned the conventional separation of powers analysis undergirding the administrative state, ${ }^{25}$ it behooves administrative law scholars to

Mont. Aug. 3, 2018) (finding it "appropriate to follow [the en banc D.C. Circuit's $P H H$ decision] to determine that the structure of the CFPB comports with the Constitution"); Consumer Fin. Prot. Bureau v. All Am. Check Cashing, Inc., No. 3:16-cv-356-WHB-JCG, 2018 WL 9812125, at*2 (S.D. Miss. Mar. 21, 2018) (finding the CFPB's structure constitutional "for the same reasons stated in PHH Corp."), appeal docketed, No. 18-60302 (5th Cir. Apr. 24, 2018).

20. RD Legal Funding, 332 F. Supp. 3d at 784.

21. See Collins, 896 F.3d at 659-72. The FHFA, like the CFPB, is headed by a single director, rather than a multimember body. 12 U.S.C. § 4512(b) (2012). After an en banc rehearing, the Fifth Circuit reinstated the part of the panel opinion finding the FHFA's structure unconstitutional. Collins v. Mnuchin, 938 F.3d 553, 588 (5th Cir. 2019) (en banc), petition for cert. filed, No. 19-422 (U.S. Sept. 25, 2019).

22. See generally Petition for Writ of Certiorari, Seila Law LLC v. Consumer Fin. Prot. Bureau, No. 19-7 (U.S. argued Mar. 3, 2020), 2019 WL 2763117.

23. PHH Corp. v. Consumer Fin. Prot. Bureau, 881 F.3d 75, 165 (D.C. Cir. 2018) (en banc) (Kavanaugh, J., dissenting).

24. Martin Shapiro, A Golden Anniversary?: The Administrative Procedures Act of 1946, 19 REG. 40, 40-41 (1996).

25. See, e.g., Lucia v. SEC, 138 S. Ct. 2044, 2055 (2018) (holding that Administrative Law Judges (ALJs) of the Securities and Exchange Commission are "'Officers of the United States[]' subject to the Appointments Clause"). The Trump administration did not hesitate to use Lucia v. $S E C$ to increase executive control of the administrative state. Guidance on Administrative Law Judges After Lucia v. SEC (S. Ct.), July 2018, 132 HARV. L. REv. 1120, 1120-22 (2019). Shortly after the Court handed down its opinion in Lucia, the Trump administration issued an executive order exempting all ALJs appointed under 5 U.S.C. $§ 3105$ from competitive selection and 
assess the implications of Judge Kavanaugh's $P H H$ dissent going forward. The implications are threefold: (1) a reframing of analysis to focus on an agency's unaccountable power; (2) serious doubts about the constitutionality of the SSA; and (3) further erosion of the doctrinal foundations of independent agencies.

Part I of this Comment examines the unitary executive theory. It then details the doctrinal framework for presidential removal power arising from Supreme Court precedent and reviews the D.C. Circuit's PHH decision and the Fifth Circuit's Collins decision. Section II.A argues that Judge Kavanaugh's $P H H$ dissent and the Fifth Circuit's Collins decision dramatically depart from the Supreme Court's removalpower precedent and assesses how Judge Kavanaugh's approach might relate to the removal-power doctrine. Section II.B begins with the following premise: if the Supreme Court adopts Judge Kavanaugh's approach, it must develop coherent standards to determine, in Justice Scalia's words, "how the balance is to be struck." ${ }^{26}$ Protecting individual liberty is certainly a broad purpose of the separation of powers, but it is not a judicially manageable constitutional standard.

This Comment articulates a workable framework for assessing the constitutional validity of for-cause removal provisions under Judge Kavanaugh's approach. In particular, it identifies three critical categories of factors courts must scrutinize to determine the constitutionality of an agency's independence: (1) the nature and scope of power Congress confers upon the agency; (2) internal political control; and (3) external political control. In so doing, this Comment demonstrates that Judge Kavanaugh's approach to the removal power transforms the SSA - an independent agency upon which sixty-four million Americans depend ${ }^{27}$-into an agency subject to the political whims of a President. It reaches this conclusion after assessing the cumulative effect of the SSA's structural features, including: (1) the nature and scope of power congressionally conferred upon the SSA; (2) the lack of indirect political safeguards; and (3) the lack of external political control.

This Comment concludes by cautioning against the adoption of

\footnotetext{
examination and a subsequent guidance memorandum "extending Lucia's reasoning to all ALJs and 'similarly situated' non-ALJ adjudicators." Id. (citing Exec. Order No. 13,843, 83 Fed. Reg. 32,755 (July 10, 2018); Memorandum from the Solicitor General, U.S. Dep't of Justice, to Agency Gen. Counsels, Guidance on Administrative Law Judges After Lucia v. SEC (S. Ct.) (July 2018)).

26. Morrison v. Olson, 487 U.S. 654, 711 (1988) (Scalia, J., dissenting).

27. See Benefits in Current Payment Status, Soc. SEC. ADMIN., https://www.ssa.gov/oact/ ProgData/icpGraph.html [https://perma.cc/96KX-B5JA] (last visited Jan. 16, 2020) (stating that 64,064,496 beneficiaries received benefits at the end of December 2019).
} 
Judge Kavanaugh's approach because, despite his assertions to the contrary, it lays the groundwork for invalidating all independent agencies, reviving a separation of powers that sharply constrains the modern administrative state. This Comment questions the assumption that presidential control over administrative agencies would increase accountability. If the accumulation of unchecked power is the problem, then the disease worsens with the treatment. Deliberative accountability, fostered by administrative law practices such as notice and comment and judicial review, offers a valuable check that will be sorely missed if sacrificed to the executive.

\section{BACKGROUND}

\section{A. Control of Officers}

The President has three means of controlling administrative agencies: appointment, direct oversight, and removal. This essential source of presidential power, however, is subject to both constitutional and statutory restraints.

\section{The Unitary Executive Theory}

The debate over the scope of executive power dates back to the founding. ${ }^{28}$ But legal scholars agree that Article II contemplates a "unitary" executive controlled by the President. ${ }^{29}$ The Vesting Clause vests the executive power in the President, not the executive branch. ${ }^{30}$ Similarly, the Appointments Clause gives the President, rather than the executive branch, power to appoint "Officers of the United States," 31 and the Take Care Clause imposes a duty on the President to "take Care that the Laws be faithfully executed." 32 This reflects the framers' belief that a strong, unified executive was necessary for political accountability and prompt, concerted responses to national crises. ${ }^{33}$ While it is clear that the

28. Peter M. Shane, The Originalist Myth of the Unitary Executive, 19 U. PA. J. CONST. L. 323, 324 (2016).

29. Robert L. Glicksman \& Richard E. LeVy, Administrative LaW: AgenCy ACtion in LEGAL CONTEXT 83 (2d ed. 2015).

30. U.S. ConsT. art. II, $\S 1$, cl. 1 ("The executive Power shall be vested in a President of the United States of America.").

31. Id. $\S 2, \mathrm{cl} .2$.

32. Id. $\S 3$.

33. See, e.g., The Federalist No. 70, at 421-23 (Alexander Hamilton) (Clinton Rossiter ed., 2003) ("Energy in the Executive ... is essential to the protection of the community against foreign attacks .... That unity is conducive to energy will not be disputed. Decision, activity, secrecy, and 
President has control over executive officers, legal scholars continue to debate the extent of that control and its implications for administrative agencies in general, and independent agencies in particular. ${ }^{34}$ The Supreme Court has thus far rejected the extreme view that the Constitution contemplates a rigid, absolute unitary executive. ${ }^{35}$ Both constitutional and statutory checks and balances constrain the President's control over the executive branch.

\section{The Removal Power}

The President's removal power is generally considered as "perhaps the key means" of control over executive officers. ${ }^{36}$ The mere threat of removal allows the President to exert powerful political pressure on the policy direction of administrative agencies. ${ }^{37}$ The President's removal

dispatch will generally characterize the proceedings of one man in a much more eminent degree than the proceedings of any greater number; and in proportion as the number is increased, these qualities will be diminished.").

34. Compare Datla \& Revesz, supra note 13, at 769 (arguing that all administrative agencies "should be regarded as executive and seen as falling on a spectrum from more independent to less independent"), Shane, supra note 28 (challenging the originalist argument for the unitary executive theory), and Lawrence Lessig \& Cass R. Sunstein, The President and the Administration, 94 COLUM. L. REV. 1 (1994) (challenging the unitary executive theory), with STEVEN G. CALABRESI \& Christopher S. Yoo, The Unitary Executive: Presidential Power From Washington to BUSH (2008) (arguing in favor of a strong unitary executive), Steven G. Calabresi \& Saikrishna B. Prakash, The President's Power to Execute the Laws, 104 YALE L.J. 541 (1994) (same), and Steven G. Calabresi \& Kevin H. Rhodes, The Structural Constitution: Unitary Executive, Plural Judiciary, 105 HARV. L. REV. 1153 (1992) (same).

35. See Humphrey's Ex'r v. United States, 295 U.S. 602, 620, 631-32 (1935) (rejecting the unitary executive theory by allowing Congress to limit the President's power to remove commissioners of the Federal Trade Commission only for "inefficiency, neglect of duty, or malfeasance in office"); Morrison v. Olson, 487 U.S. 654, 688-93 (1988) (reaffirming the Court's rejection of the unitary executive theory in Humphrey's Executor and permitting Congress to limit the Attorney General's power to remove an independent counsel appointed to investigate the executive branch to "good cause"); see also Free Enter. Fund v. Pub. Co. Accounting Oversight Bd., 561 U.S. 477, 483-84, 501 (2010) (invalidating two layers of for-cause removal protection, an "unusual situation, never before addressed by the Court," without displacing Humphrey's Executor and Morrison).

36. Free Enter. Fund, 561 U.S. at 501 (quoting 1 ANNALS OF CONG. 463 (1789) (Joseph Gales ed., 1834)); GLICKSMAN \& LEVY, supra note 29, at 85 ("In practice, the most important control a President has over administrative officials is the ability to remove them from office."); see also Myers v. United States, 272 U.S. 52, 132 (1926) ("Made responsible under the Constitution for the effective enforcement of the law, the President needs as an indispensable aid to meet it the disciplinary influence upon those who act under [them] of a reserve power of removal."). But see Jonathan L. Entin, Synecdoche and the Presidency: The Removal Power as Symbol, 47 CASE W. RES. L. REV. 1595, 1595 (1997) (arguing that the removal power has "limited real-world significance").

37. See Cary Coglianese, The Emptiness of Decisional Limits: Reconceiving Presidential Control of the Administrative State, 69 ADMIN. L. REV. 43, 57-58 (2017) ("Outside of criminal acts, the threat to remove an agency head is probably the most serious threat that any president can wield 
power sparked some of the earliest and most critical constitutional disputes in U.S. history, ${ }^{38}$ in large part because, aside from the Impeachment Clause,${ }^{39}$ the Constitution contains no provision expressly authorizing the President to remove executive officers. ${ }^{40}$ The topic was never even discussed at the Constitutional Convention. ${ }^{41}$ Nevertheless, the Court has long recognized that the President has an inherent power of removal. ${ }^{42}$ Congress, however, often places statutory limits on the President's power to remove executive officers. ${ }^{43}$ After all, an officer who holds office "only during the pleasure of" the President "cannot be depended upon to maintain an attitude of independence against the latter's will."44 Ultimately, although the President must have the power to remove executive officers who fail to faithfully execute the law, the Supreme Court upheld for-cause removal restrictions in a series of cases, allowing Congress to create independent agencies.

In Myers v. United States, the Court struck down a statutory provision conditioning removal of first-class postmasters on "the advice and consent of the Senate." required the President to have "unrestricted power ... to remove [their]

in the administrative context."); Michele Estrin Gilman, The President As Scientist-in-Chief, 45 Willamette L. REV. 565, 601 (2009) ("Of course, Congress competes with the President to control agencies... . Particularly if the President is directing agency outcomes, [they] can diminish the impact of congressional oversight because the threat of removal can be more powerful than that of the purse.").

38. CALABRESI \& YOO, supra note 34 , at 3.

39. U.S. CONST. art. II, $\S 4$ ("The President, Vice President and all civil Officers of the United States, shall be removed from Office on Impeachment for, and Conviction of, Treason, Bribery, or other high Crimes and Misdemeanors.").

40. See Myers v. United States, 272 U.S. 52, 109 (1926).

41. Id. at 109-10.

42. See id. at 163-64 ("Article II grants to the President the executive power of the Government ... including the power of appointment and removal of executive officers."); see also Free Enterprise Fund v. Pub. Co. Accounting Oversight Bd., 561 U.S. 477, 492 (2010) (explaining that the Court has recognized since 1789 that "the executive power include[s] a power to oversee executive officers through removal").

43. E.g., 12 U.S.C. § 5491(c)(3) (2018) (CFPB); 42 U.S.C. § 1975(e) (2012) (Commission on Civil Rights) (2012); 15 U.S.C. § 2053(a) (2018) (Consumer Product Safety Commission); 12 U.S.C. § 4512(b)(2) (FHFA) (2018); 5 U.S.C. § 7104(b) (2018) (Federal Labor Relations Authority); 46 U.S.C. $\S 301(\mathrm{~b})(3)$ (2012) (Federal Maritime Commission); 12 U.S.C. $\S 242$ (2018) (Federal Reserve); 15 U.S.C. § 41 (2018) (FTC); 30 U.S.C. § 823(b)(1) (2012) (Mine Safety and Heath Review Commission); 29 U.S.C. § 153(a) (2012) (National Labor Relations Board (NLRB)); 45 U.S.C. § 154 (2012) (National Mediation Board); 49 U.S.C. § 1111(c) (2012) (National Transportation Safety Board); 29 U.S.C. $§ 661(b)$ (2012) (Occupational Safety and Health Review Commission); 5 U.S.C. § 1211(b) (2018) (Office of Special Counsel); 39 U.S.C. § 502(a) (2012) (Postal Regulatory Commission); 42 U.S.C. § 902(a)(3) (2012) (Social Security Administration); 39 U.S.C. § 202(a)(1) (2012) (United States Postal Service).

44. Humphrey's Ex'r v. United States, 295 U.S. 602, 629 (1935).

45. 272 U.S. at $176-77$. 
appointees," flowing from the "general grant ... of the executive power" and the "constitutional duty of seeing that the laws be faithfully executed." 46 Although Chief Justice Taft's Myers opinion contained broad language suggesting complete presidential removal power, ${ }^{47}$ the Court subsequently cabined Myers's apparent reach. ${ }^{48}$ In Humphrey's Executor v. United States, the Court unanimously upheld a statutory limitation on the President's power to remove members of the Federal Trade Commission (FTC). ${ }^{49}$ The Court distinguished Myers on the ground that a postmaster is a purely executive officer, whereas the FTC is a quasi-legislative or quasi-judicial administrative agency, "occup[ying] no place in the executive department." 50 Congress's authority to insulate quasi-legislative or quasi-judicial agencies from executive control, the Court added, "cannot well be doubted." In upholding the for-cause removal protection as a permissible means of ensuring that FTC Commissioners "maintain an attitude of independence" from the President's control, ${ }^{52}$ the Court made clear that Myers did no more than establish the principle that the President must be able remove at will subordinate officers in the executive branch. ${ }^{53}$

In Bowsher v. Synar, the Court invalidated statutory provisions delegating executive power to the Comptroller General, a legislative officer removable only by joint resolution of Congress for cause. ${ }^{54}$ Relying on Myers, the Court concluded broadly that "Congress cannot reserve for itself the power of removal of an officer charged with the

46. Id. at $134-35$.

47. See id. at 163-64. The Court's decision relied primarily on a strong unitary executive interpretation of the so-called decision of 1789. See id. at 163. The Court emphasized that for seventy-four years after the decision of 1789, "no act of Congress, no executive act, and no decision of this court [was] at variance with the declaration of the First Congress," but, interestingly, downplayed the fact that a number of Presidents had approved legislation restricting their own removal power. $I d$. at $163,170$.

48. See Wiener v. United States, 357 U.S. 349, 352 (1958) ("Within less than ten years a unanimous Court, in Humphrey's Executor v. United States, narrowly confined the scope of the Myers decision to include only 'all purely executive officers." (citation omitted) (quoting Humphrey's Ex'r v. United States, 295 U.S. 602, 628 (1935)). Myers is generally regarded as the "high-water mark of the unitary executive theory." Neomi Rao, A Modest Proposal: Abolishing Agency Independence in Free Enterprise Fund v. PCAOB, 79 FORDHAM L. REV. 2541, 2551 (2011).

49. 295 U.S. 602, 619, 631-32 (1935). Under the Federal Trade Commission Act, the President may remove a Commissioner only for "inefficiency, neglect of duty, or malfeasance in office." 15 U.S.C. $\S 41$ (2018).

50. Humphrey's Ex'r, 295 U.S. at 628.

51. Id. at 629 .

52. Id.

53. Id. at 627-28.

54. 478 U.S. 714,734 (1986). 
execution of the laws except by impeachment." 55 Two years later, the Court in Morrison v. Olson upheld the constitutionality of an independent counsel position established in the wake of the Watergate scandal to investigate wrongdoing in the executive branch, removable only for cause by the Attorney General. ${ }^{56}$ Although the independent counsel performed "quintessentially executive" functions, ${ }^{57}$ the Court made clear that the official's functions were not dispositive. The "real question" for the Court was whether the inability to remove an officer at will interfered with the President's ability to perform their Article II duty to ensure the faithful execution of the laws. ${ }^{58}$ While the independent counsel exercised significant discretion and independent judgment, the officer was an inferior officer who possessed only "limited jurisdiction" and "lack[ed] policymaking or significant administrative authority." 59 The Court therefore could "not see how the President's need to control the exercise of that discretion [was] so central to the functioning of the Executive Branch as to require ... that the counsel be terminable at will by the President." 60

Free Enterprise Fund v. PCAOB, the Court's most recent removalpower decision, purported to apply Morrison's functional inquiry to invalidate two layers of for-cause removal protection. ${ }^{61}$ Free Enterprise Fund involved the Sarbanes-Oxley Act of 2002, ${ }^{62}$ which allowed members of the U.S. Securities and Exchange Commission (SEC) to remove members of the Public Company Accounting Oversight Board (PCAOB) only for cause. ${ }^{63}$ The SEC Commissioners, in turn, could only be removed by the President for cause. ${ }^{64}$ The Court held that these two

55. Id. at 726 ("To permit the execution of the laws to be vested in an officer answerable only to Congress would, in practical terms, reserve in Congress control over the execution of the laws."). As a remedy, the Court chose to strip the Comptroller of executive power, rather than perform "creative and imaginative statutory surgery" and sever the removal provisions. Id. at 736.

56. 487 U.S. 654, 696-97 (1988).

57. Id. at 706 (Scalia, J., dissenting) ("[The independent counsel] is vested with the 'full power and independent authority to exercise all investigative and prosecutorial functions and powers of the Department of Justice [and] the Attorney General.' . . . Governmental investigation and prosecution of crimes is a quintessentially executive function." (citations omitted)).

58. Id. at 691 (majority opinion).

59. Id.

60. Id. at 691-92.

61. 561 U.S. 477, 483-84 (2010).

62. Pub. L. No. 107-204, 116 Stat. 745 (2002) (codified as amended in scattered sections of the U.S. Code).

63. Free Enter. Fund, 561 U.S. at 495.

64. Id. at 487. The President could only remove SEC Commissioners for "inefficiency, neglect of duty, or malfeasance in office." Id. (quoting Humphrey's Ex'r v. United States, 295 U.S. 602, $620(1935))$. 
layers of for-cause removal protection - a "Matryoshka doll of tenure protections"- -unduly diluted the President's control over the executive branch. $^{65}$ As a remedy, the Court severed the PCAOB's for-cause removal provision, but left intact the SEC Commissioners' for-cause removal protection. ${ }^{66}$ In $P H H,{ }^{67}$ a D.C. Circuit panel stretched the Court's approach in Free Enterprise Fund to invalidate the CFPB's structure. ${ }^{68}$

\section{B. PHH Corp. v. Consumer Financial Protection Bureau}

In the aftermath of the 2008 financial crisis, ignited by the collapse of mortgage-backed securities, ${ }^{69}$ Congress established the CFPB under the Dodd-Frank Wall Street Reform and Consumer Protection Act of $2010^{70}$ to enforce federal consumer financial laws consistently and protect consumers from financial abuse. ${ }^{71}$ To accomplish these goals, Congress gave the CFPB extensive rulemaking, ${ }^{72}$ supervisory, ${ }^{73}$ and enforcement ${ }^{74}$ powers, including the authority to issue cease-and-desist orders after a formal adjudication proceeding. ${ }^{75}$ To ensure independence, Dodd-Frank places the CFPB outside the annual appropriations process and in the Federal Reserve System, an independent bureau. ${ }^{76}$ DoddFrank also provides for a single director to lead the agency. ${ }^{77}$ The CFPB

65. Id. at 497,514

66. Id. at 508-09 ("Concluding that the removal restrictions are invalid leaves the Board removable by the Commission at will, and leaves the President separated from Board members by only a single level of good-cause tenure. The Commission is then fully responsible for the Board's actions, which are no less subject than the Commission's own functions to Presidential oversight.").

67. PHH Corp. v. Consumer Fin. Prot. Bureau (PHH I), 839 F.3d 1 (D.C. Cir. 2016), rev'd en banc, 881 F.3d 75 (D.C. Cir. 2018).

68. See infra Section II.A.

69. See S. REP. NO. 111-176, at 14 (2010). For a thorough account of the anatomy of the 2008 financial crisis, see Neil Fligstein \& Adam Goldstein, The Anatomy of the Mortgage Securitization Crisis, in 30A MARKeTS ON TRIAL: The ECONOMIC SOCIOlOGY OF THE U.S. FinANCIAL CRISIS: PART A 29-70 (Michael Lounsbury \& Paul M. Hirsch eds., 2010).

70. Pub. L. No. 111-203, 124 Stat. 1376 (2010) (codified as amended in scattered sections of the U.S. Code).

71. See 12 U.S.C. § 5511(a)-(b) (2018). The CFPB consolidated consumer financial protection authorities that previously existed across seven federal agencies under one roof to ensure government accountability. See S. REP. No. 111-176, at 11.

72. See 12 U.S.C. $\S 5512$.

73. See id. $\$ \S 5514-5515$.

74. See id. $\S \S 5561-5567$.

75. Id. $\S 5563(\mathrm{~b})$.

76. Id. $\S 5491$ (a). Each year, the CFPB Director may request a "reasonably necessary" funding amount from the Federal Reserve, up to a statutory funding cap. Id. § 5497(a). The Federal Reserve, the President, and Congress have no influence. See id.

77. Id. § 5491(b). 
Director, appointed by the President with Senate consent, serves a fiveyear term, during which they may not be removed by the President without cause. ${ }^{78}$

The D.C. Circuit addressed the constitutionality of the CFPB's structure in PHH Corp. v. Consumer Financial Protection Bureau. ${ }^{79}$ The case arose out of a mortgage lender's alleged violations of the Real Estate Settlement Procedures Act of 1974 (RESPA), which prohibits mortgage kickbacks in exchange for referrals. ${ }^{80}$ In 2014, the CFPB filed a Notice of Charges against PHH Corporation, PHH Mortgage Corporation, PHH Home Loans, LLC, Atrium Insurance Corporation, and Atrium Reinsurance Corporation (collectively, PHH), alleging RESPA violations. ${ }^{81}$ An administrative law judge (ALJ) first adjudicated the charges and found that PHH violated RESPA's prohibition against kickbacks. ${ }^{82}$ The ALJ recommended a disgorgement of approximately $\$ 6.4$ million in reinsurance premiums. ${ }^{83}$ On review, the CFPB Director upheld the ALJ's RESPA violations finding but adopted a broader interpretation of RESPA, raising the disgorgement amount to over \$109 million. ${ }^{84}$ PHH appealed the CFPB Director's decision on multiple grounds, including the constitutionality of the CFPB's structure. ${ }^{85}$

In a hundred-page opinion penned by Judge Kavanaugh, a divided panel's majority held that the CFPB Director's protection from removal at will violates the Constitution's separation of powers by vesting "substantial executive authority" in a single individual unaccountable to the President. ${ }^{86}$ Because the CFPB's structure is not analogous to the dual-layer tenure structure of the PCAOB in Free Enterprise Fund, the

78. Id. §5491(c) ("The President may remove the Director for inefficiency, neglect of duty, or malfeasance in office.").

79. PHH Corp. v. Consumer Fin. Prot. Bureau (PHH II), 881 F.3d 75, 77 (D.C. Cir. 2018) (en banc).

80. PHH I, 839 F.3d 1, 10-11 (D.C. Cir. 2016). Specifically, RESPA provides that "[n]o person shall give and no person shall accept any fee, kickback, or thing of value pursuant to any agreement or understanding, oral or otherwise, that business incident to or a part of a real estate settlement service involving a federally related mortgage loan shall be referred to any person." $\S$ 2607(a).

81. PHH II, 881 F.3d at 82 . The CFPB alleged that "[t]he premiums ceded by [mortgage insurers] to PHH through [its captive insurer]: (a) were not for services actually furnished or performed, or (b) grossly exceeded the value of any such services, and that the premiums were instead made in consideration of PHH's continued referral of mortgage insurance business." Id. (internal quotation marks omitted).

82. Id.

83. $I d$.

84. Id. at $82-83$.

85. $P H H I, 839$ F.3d at 7.

86. Id. at 16,36 . 
panel had to distinguish the CFPB's structure from Humphrey's Executor and Morrison to find it unconstitutional. Judge Kavanaugh distinguished the cases on the ground that Dodd-Frank, in an allegedly unprecedented move, provided for a single individual to head an independent agency. ${ }^{87}$ Judge Kavanaugh declared the Director of the CFPB "the single most powerful official in the entire United States Government [other than the President], at least when measured in terms of unilateral power." 88 Judge Kavanaugh reasoned that independent agencies are not accountable to the President, and that the multimember structure "acts as a critical substitute check" in lieu of presidential control. ${ }^{89}$ By concentrating "massive," "enormous" power over "vast swaths of American economic and social life" in a single, unaccountable individual, that critical check is absent from the CFPB, posing "a far greater risk of arbitrary decisionmaking and abuse of power, and a far greater threat to individual liberty, than does a multi-member independent agency." 90 As a remedy, Judge Kavanaugh severed the for-cause removal provision from the CFPB's enabling act. ${ }^{91}$

After an en banc rehearing, the D.C. Circuit vacated the panel decision and upheld the constitutionality of the CFPB's structure. ${ }^{92}$ The 7-3 majority found nothing about the CFPB that stood out to "give [it] pause" that the agency's structure is unconstitutional. ${ }^{93}$ In evaluating whether the CFPB Director's for-cause removal protection unconstitutionally interferes with the President's Article II duty, the en banc majority noted that the removal protection at issue is "the verbatim protection" upheld in Humphrey's Executor ${ }^{94}$ and that the autonomy of the CFPB Director, whose functions are not "core executive functions," is "consistent with a longstanding tradition of independence for financial regulators." member majority or Justice Scalia's dissent in Morrison suggested the

87. Id. at $6-7,17$ (stating that "no independent agency exercising substantial executive authority has ever [previously] been headed by a single person" and that the CFPB is "a historical anomaly").

88. Id. at 16 .

89. Id. at 8 .

90. Id. at 8,15 .

91. Id. at 8 .

92. PHH II, 881 F.3d 75, 100 (D.C. Cir. 2018) (en banc) ("The CFPB led by a single Director is as consistent with the President's constitutional authority as it would be if it were led by a group.").

93. Id. at 93 .

94. Id. Just as the statutory provision at issue in Humphrey's Executor provides, the President may remove the CFPB Director for "inefficiency, neglect of duty, or malfeasance in office." Compare 15 U.S.C. $\$ 41$ (2018) (FTC), with 12 U.S.C. § 5491(c)(3) (2018) (CFPB).

95. PHH II, 881 F.3d at $84,93$. 
fact that the independent counsel was a "solo actor" was material to the analysis. ${ }^{96}$ The en banc majority concluded that any intellectually consistent reading of the Court's removal-power precedent-particularly Morrison and Humphrey's Executor-required finding the CFPB's leadership structure constitutional. ${ }^{97}$ The en banc majority's analysis follows the existing Supreme Court case law.

The en banc majority also rejected PHH's "untenable" distinction between an independent agency headed by a single individual and one headed by a multimember body vis-à-vis presidential removal power, ${ }^{98}$ describing PHH's position as a "wholesale attack on independent agencies... that, if accepted, would broadly transform modern government." "99 In his concurrence, Circuit Judge Tatel added that "PHH is free to ask the Supreme Court to revisit Humphrey's Executor and Morrison, but that argument has no truck in a circuit court of appeals."100 The en banc majority thus upheld the CFPB Director's for-cause removal protection. $^{101}$ Judge Kavanaugh dissented from the en banc decision overruling his panel opinion. ${ }^{102}$ Judge Kavanaugh's reasoning in his dissent, which closely tracked his $\mathrm{PHH}$ panel opinion, was heavily relied upon by the Fifth Circuit in assessing the constitutionality of the FHFA's single-director structure. ${ }^{103}$

\section{Collins v. Mnuchin}

Three years before establishing the CFPB, Congress enacted the Housing and Economic Recovery Act of 2008 (HERA) to help stabilize the unraveling housing market. ${ }^{104}$ HERA sought to increase governmental control over two government-sponsored enterprises (GSEs), ${ }^{105}$ the Federal National Mortgage Association (Fannie Mae) and

96. Id. at 96 .

97. Id. at 93. The CFPB's budgetary independence did not affect this analysis. Id. at 96 .

98. Id. at 79-80, 96 (“[T]

99. Id. at 80; see also Opening En Banc Brief for Petitioners at 22 n.4, PHH II, 881 F. $3 \mathrm{~d} 75$ (No. 15-1177) (preserving argument for overruling Morrison and Humphrey's Executor).

100. PHH II, 881 F.3d. at 113 (Tatel, J., concurring).

101. Id. at 110 .

102. Id. at 164-200 (Kavanaugh, J., dissenting).

103. See Collins v. Mnuchin, 896 F.3d 640, 659-72 (5th Cir. 2018), aff'd in part, rev'd in part en banc, 938 F.3d 553 (5th Cir. 2019), petition for cert. filed, No. 19-422 (U.S. Sept. 25, 2019).

104. Pub. L. No. 110-289, 122 Stat. 2654 (codified as amended at 12 U.S.C. $\S \S 4501-4642$ (2018)).

105. A government-sponsored enterprise is "a privately owned, federally-chartered financial institution with nationwide scope and specialized lending powers that benefits from an implicit federal guarantee." THOMAS H. STANTON, GOVERNMENT-SPONSORED ENTERPRISES: 
the Federal Home Loan Mortgage Corporation (Freddie Mac), together the dominant players in the mortgage-backed securities market. ${ }^{106}$ HERA created the FHFA to oversee Fannie Mae and Freddie Mac, and empowered it to act as both regulator and conservator of the GSEs. ${ }^{107}$ Congress determined that the FHFA, like the CFPB, needed independence to insulate the agency from the political pressure that plagued past regulators, and placed the agency outside the normal appropriations process. ${ }^{108}$ To lead the agency, Congress provided for a single director, appointed for a five-year term, removable by the President only for cause. ${ }^{109}$

In Collins v. Mnuchin, a split three-judge panel of the Fifth Circuit held that the FHFA's structure violates the Constitution's separation of powers. ${ }^{110}$ Rather than create a circuit split, the court sought to distinguish $P H H$ based on "salient distinctions" between the FHFA and CFPB. ${ }^{111}$ But the Fifth Circuit's reasoning and repeated citations to Judge Kavanaugh's $\mathrm{PHH}$ dissenting opinion suggest it was more sympathetic to Judge Kavanaugh's views than those of the majority. Nevertheless, the court's analysis began with the premise that "agencies may be independent," but they may not be so insulated as to become effectively "isolated." 112 The court recognized the difficulty in measuring insulation, but insisted that it must "remain faithful" to Free Enterprise Fund. ${ }^{113}$ The court argued that Free Enterprise Fund requires a fact-specific inquiry to determine whether a for-cause removal provision "working together" with other statutory provisions excessively

MERCANTILIST COMPANIES IN THE MODERN WORLD 1-2 (2002).

106. 12 U.S.C. $\S 4501(2)$ (2018) ("[B]ecause the continued ability of the Federal National Mortgage Association and the Federal Home Loan Mortgage Corporation to accomplish their public missions is important to providing housing in the United States and the health of the Nation's economy, more effective Federal regulation is needed to reduce the risk of failure of the enterprises.").

107. Id. $\S \S 4511,4617$. Conservatorship is "a statutory process designed to stabilize a troubled institution with the objective of returning [it] to normal business operations." Press Release, Fed. Hous. Fin. Agency, Statement of FHFA Director James B. Lockhart at News Conference Announcing Conservatorship of Fannie Mae and Freddie Mac (Sept. 7, 2008), https://www.fhfa.gov /Media/PublicAffairs/Pages/Statement-of-FHFA-Director-James-B-Lockhart-at-News-ConferenceAnnnouncing-Conservatorship-of-Fannie-Mae-and-Freddie-Mac.aspx [https://perma.cc/VVL6ZJDA].

108. See 12 U.S.C. $\S 4516$ (2018).

109. Id. $\S 4512$ (b).

110. 896 F.3d 640, 646 (5th Cir. 2018), aff'd in part, rev'd in part en banc, 938 F.3d 553 (5th Cir. 2019), petition for cert. filed, No. 19-422 (U.S. Sept. 25, 2019).

111. See id. at 673.

112. Id. at 662 .

113. Id. at 666 n.196 (citing Free Enter. Fund v. Pub. Co. Accounting Oversight Bd., 561 U.S. $477,509(2010))$. 
insulate an agency, "produc[ing] a constitutional violation."114

The Fifth Circuit found the FHFA "too insulated" from executive oversight. ${ }^{115}$ In reaching its decision, the court assessed the cumulative effect of five insulating mechanisms: "(1) for-cause removal restriction; (2) single-director leadership structure; (3) lack of a bipartisan leadership composition requirement; (4) funding stream outside the normal appropriations process; and (5) Federal Housing Finance Oversight Board's purely advisory oversight role."116 Whatever the merits of the court's argument that these elements are insulation mechanisms, the first four present in the FHFA were also present in the CFPB. ${ }^{117}$ The only true distinguishing factor between the FHFA and the CFPB is that "the Executive Branch can directly control the CFPB's actions" via the Financial Stability Oversight Council. ${ }^{118}$ The FSOC holds veto-power over the CFPB, allowing the FSOC to set aside CFPB regulations that put the "safety and soundness" of the U.S. banking system or financial system at risk. ${ }^{119}$ In contrast, the FHOFB "exercises purely advisory functions," as it "cannot require the FHFA or Director to do anything" other than order a board meeting. ${ }^{120}$ The court concluded that Congress "encased the FHFA in so many layers of insulation," creating an agency unaccountable to the President in violation of Article II. ${ }^{121}$ The court's solution was to sever the removal restriction from HERA, "restoring Executive Branch oversight to the FHFA."122

The Fifth Circuit subsequently agreed to hear the case en banc. ${ }^{123}$ The en banc court reinstated the portion of the panel decision finding the FHFA's structure unconstitutional. ${ }^{124}$ In so doing, the en banc court sought to clarify yet again that the panel opinion "distinguishes the D.C.

\footnotetext{
114. Id. (quoting Free Enter. Fund, 561 U.S. at 509).

115. Id. at 661,666

116. Id. at $666-70$.

117. See supra notes $76-78$ and accompanying text.

118. Collins, 896 F.3d at 673 .

119. 12 U.S.C. $\$ 5513$ (a) (2018).

120. Collins, 896 F.3d at 669 .

121. Id. at 674 (citing Free Enter. Fund v. Pub. Co. Accounting Oversight Bd., 561 U.S. 477, 496 (2010)).

122. Id. at 676. Recognizing that the removal restriction was "just one of several provisions" that, when combined, violated the separation of powers, the court refused to make any other edits to HERA because "such editorial freedom ... belongs to the Legislature, not to the Judiciary." Id. (quoting Free Enter. Fund, 561 U.S. at 510).

123. See Collins v. Mnuchin, 908 F.3d 151 (5th Cir. 2018).

124. See Collins v. Mnuchin, 938 F.3d 553, 587-88 (5th Cir. 2019) (en banc), petition for cert. filed, No. 19-422 (U.S. Sept. 25, 2019).
} 
Circuit's PHH Corp. decision." ${ }^{25}$ But this distinction is untenable. ${ }^{126}$ Collins v. Mnuchin creates a circuit split on the issue of the constitutionality of the single-head structure.

\section{ANALYSIS}

Collectively, the Supreme Court's removal-power cases involve two distinct issues raised by statutory limits on the President's removal power. The first issue concerns the means of independence. The President's Article II duty to take care that the laws are faithfully executed is clear and specific: any provision that prevents the President from removing an "unfaithful" officer-that is, an officer that fails to faithfully execute the law-is per se invalid. ${ }^{127}$ Because provisions that condition removal on Senate consent or a joint resolution of Congress may prevent the President from removing an unfaithful officer, such requirements are invalid. ${ }^{128}$ In Free Enterprise Fund, the Court extended this principle to invalidate two layers of for-cause removal protection. ${ }^{129}$ In contrast, the Court has repeatedly held that a single layer of for-cause removal protection does not violate the Take Care Clause because the protection does not prevent the removal of an unfaithful officer. ${ }^{130}$

The second issue concerns the validity of policy independence. Forcause removal protection gives an officer policy independence because her failure — or refusal — to act in accordance with the President's policy preferences does not constitute a failure to faithfully execute the laws. ${ }^{131}$ In other words, the President does not have good cause for removal merely because an officer does not to align with their policy preferences. Nonetheless, this sort of policy independence arguably violates the unitary executive theory implicit in Article II's Vesting Clause.

\section{Id. at 588 .}

126. See infra notes 203-13 and accompanying text.

127. See Free Enter. Fund v. Pub. Co. Accounting Oversight Bd., 561 U.S. 477, 484 (2010) ("The President cannot 'take Care that the Laws be faithfully executed' if [they] cannot oversee the faithfulness of the officers who execute them."); Bowsher v. Synar, 478 U.S. 714, 726 (1986) ("To permit the execution of the laws to be vested in an officer answerable only to Congress would, in practical terms, reserve in Congress control over the execution of the laws.... The structure of the Constitution does not permit Congress to execute the laws.").

128. See Myers v. United States, 272 U.S. 52, 122-24 (1926); Bowsher, 478 U.S. at 726.

129. 561 U.S. at 484.

130. See Humphrey's Ex'r v. United States, 295 U.S. 602, 630-32 (1935); Morrison v. Olson, 487 U.S. 654, 696 (1988).

131. See Clinton Rossiter, The American Presidency 18 (2d ed. 1960) (characterizing unfettered removal power as the "gun behind the door" that allows the President to "bend" agency heads "to [their] will"). 
Humphrey's Executor and Morrison resolved the policy-independence concern by using an "essential" or "core functions" test, which asks if policy independence interferes with the President's control over the "essential" or "core functions" of the executive branch. ${ }^{132}$ In assessing the validity of for-cause removal provisions, Humphrey's Executor and Morrison emphasize (1) the nature of the agency functions as either "core executive" functions, such as those entrusted to a secretary of state or other cabinet officer, or "quasi-legislative or quasi-judicial functions," 133 and (2) the scope of policy discretion and authority the independent agency wields. ${ }^{134}$ The Court repeatedly holds that where "a degree of independence from the Executive . . . is necessary to the proper functioning of the agency or official," a single layer of for-cause removal protection does not impermissibly interfere with the President's Article II constitutional role. ${ }^{135}$ A single layer of for-cause removal protection is therefore valid, unless the resulting independence of those officers interferes with the President's essential functions. ${ }^{136}$

Under this conventional analysis, courts assess the constitutionality of a for-cause removal provision for a single agency head in the same way - by focusing on the nature of the officer's functions and the scope of her policy discretion and authority. Judge Kavanaugh's approach to the removal power, however, departs dramatically from the conventional analysis.

\section{A. Judge Kavanaugh's (Unprecedented) Approach to the Removal Power}

Judge Kavanaugh's approach to the removal power in $P H H$ is entirely novel. First, Supreme Court precedent makes clear that a singlelayer of protection from removal at will does not violate the Take Care Clause because the President has the power to remove officers for good cause - a power the Court "ha[s] already concluded provides the Executive with substantial ability to ensure that the laws are 'faithfully executed." "137 In this respect, Free Enterprise Fund is not directly

132. See Humphrey's Ex'r, 295 U.S. at 627-30; Morrison, 487 U.S. 669, 690-91.

133. See Humphrey's Ex'r, 295 U.S. at 624, 629; Morrison, 487 U.S. at 688-89.

134. See Morrison, 487 U.S. at 691-92.

135. Id. at 691 n.30, 686-96; see also Wiener v. United States, 357 U.S. 349, 356 (1958); Humphrey's Ex'r, 295 U.S. at 631-32.

136. See Humphrey's Ex'r, 295 U.S. at 630; Morrison, 487 U.S. at 669; see also GLICKSMAN \& LEVY, supra note 29, at 85 ("Congress may limit the President's removal power to specified causes, provided that this limitation does not interfere with the essential functions of the President.").

137. Morrison, 487 U.S. at 696; see also Humphrey's Ex'r, 295 U.S. at 632. 
relevant to PHH (or Collins). Free Enterprise Fund is not about excessive insulation in general, but about a specific prohibition against interference with the duty to take care that the laws are faithfully executed. ${ }^{138}$ That analysis, however, is not relevant to the essential functions consideration. In fact, Free Enterprise Fund says nothing about the proper analysis for a single layer of for-cause removal protection. There, the Court left intact the SEC Commissioners' ordinary for-cause protection - the very protection that insulates the FTC, the CFPB, and other independent agencies - even as it severed the second layer. ${ }^{139}$ As Judge Kavanaugh himself recognizes, "it is black-letter law that cases are not precedent for issues that were not raised or decided." 140

Second, the essential functions consideration is concerned with whether an agency's independence interferes with the President's essential or core executive functions, not with how much unaccountable power an agency exercises. ${ }^{141}$ The $P H H$ en banc majority applied the conventional doctrine, under which the CFPB's single-head structure comports with the Take Care Clause because the President may remove the CFPB Director, who does not exercise core executive functions, for good cause:

Our analysis focuses on whether Congress's choice to include a forcause removal provision impedes the President's ability to fulfill his constitutional role. Two principal considerations inform our conclusion that it does not. First, the familiar for-cause protection at issue broadly allows the President to remove the Director for "inefficiency, neglect of duty, or malfeasance in office," leaving the President ample tools to ensure the faithful execution of the laws. Second, the functions of the CFPB and its Director are not core executive functions.... Rather, the CFPB is one of a number of federal financial regulators ... that have long been permissibly afforded a degree of independence. The CFPB matches what the Supreme Court's removal-power cases have consistently approved. ${ }^{142}$

138. For instance, in Free Enterprise Fund v. PCAOB, the extensive control that the SEC exercised over the PCAOB's actions could not salvage the dual-layered removal limitation, unless that control was virtually absolute, so as to make every unfaithful PCAOB action attributable to the SEC itself. 561 U.S. 477, 509-10 (2010).

139. Id. at 509 ("Concluding that the removal restrictions are invalid leaves the Board removable by the Commission at will, and leaves the President separated from Board members by only a single level of good-cause tenure. The Commission is then fully responsible for the Board's actions, which are no less subject than the Commission's own functions to Presidential oversight.").

140. PHH II, 881 F.3d 75, 195 (D.C. Cir. 2018) (en banc) (Kavanaugh, J., dissenting) (citing Bryan A. Garner et AL., The LaW of Judicial PreCedent 46, 84, $226-28$ (2016)).

141. See Humphrey's Ex'r, 295 U.S. at 630; Morrison, 487 U.S. at 669.

142. See PHH II, 881 F.3d at 84 (emphasis added). 
In this respect, Judge Kavanaugh's claim that the CFPB Director is not accountable is misleading at best. To the extent that Judge Kavanaugh's argument relates to other means of presidential control-such as multimember bodies, the appointment of a chair, etc.- the discussion could fit into the essential functions consideration, because other means of presidential control diminish the policy independence of the agency. Nothing in the removal-power doctrine suggests that Judge Kavanaugh's considerations are relevant. This does not necessarily mean he was wrong. But it does mean that his approach is novel and unprecedented. Nonetheless, Judge Kavanaugh in $\mathrm{PHH}$ failed to explain this connection or justify adding these considerations to the factors identified by prior Supreme Court removal-power cases. Relying heavily on Judge Kavanaugh's $\mathrm{PHH}$ dissent, the Fifth Circuit in Collins v. Mnuchin also offered no explanation or justification for this approach. ${ }^{143}$

If Judge Kavanaugh's approach garners majority support in Seila Law LLC v. Consumer Financial Protection Bureau, what will it mean for the Supreme Court's removal-power doctrine? The applicability of Judge Kavanaugh's approach might, as he alleges, be limited to independent agencies with a single-head structure, ${ }^{144}$ acting as a third constraint alongside the faithful execution of the laws test and the essential functions test for policy independence. More likely, Judge Kavanaugh's approach would replace the essential functions test for agency independence altogether, in which case his approach would become applicable to all independent agencies, irrespective of their structure. Judge Kavanaugh's approach would allow reliance on cases involving independent agencies with a single-head structure to invalidate the constitutionality of all independent agencies down the road. ${ }^{145}$

\section{B. Finding a Home for Judge Kavanaugh's Approach to the Removal Power: Protecting Liberty Is Not a Judicially Manageable Standard}

For Judge Kavanaugh, a separation of powers analysis in the context of the modern administrative state is about "executive power and

143. See generally Collins v. Mnuchin, 896 F.3d 640, 659-72 (5th Cir. 2018), aff'd in part, rev'd in part en banc, 938 F.3d 553 (5th Cir. 2019), petition for cert. filed, No. 19-422 (U.S. Sept. 25, 2019).

144. See PHH II, 881 F.3d at 164-200 (Kavanaugh, J., dissenting) (distinguishing the singlehead design from the multimember design, and noting that "Congress of course remains free, if it wishes, to reconstruct the CFPB as a traditional multi-member independent agency").

145. See id. at 80 (majority opinion) (warning that Judge Kavanaugh's approach is a "wholesale attack on independent agencies - whether collectively or individually led - that, if accepted, would broadly transform modern government"). 
individual liberty." 146 In both his $P H H$ and Free Enterprise Fund dissenting opinions, Judge Kavanaugh reminded the D.C. Circuit that the purpose of the Constitution's separation of powers is to protect individual liberty. ${ }^{147}$ To protect individual liberty, Judge Kavanaugh explained, "the Framers... separated the legislative, executive, and judicial powers of the new national government."148 However, Judge Kavanaugh's assertion that only independent agencies headed by a multimember body may be insulated from at-will removal rests largely on ad hoc judgments about whether a specific institutional design sufficiently protects "individual liberty."149 In particular, Judge Kavanaugh argued that independent agencies headed by single individuals threaten individual liberty because they present a greater risk of "arbitrary decisionmaking and abuse of power" than agencies headed by multimember bodies, which, in his view, effectively "divide and disperse power." 150 Judge Kavanaugh treats safeguarding liberty, a broad purpose of the separation of powers, as itself a judicially manageable standard. ${ }^{151}$ But as Professor John Manning explained:

[T] he purposes of the separation of powers are too general and diverse to offer much concrete guidance. Among other things, the separation of powers and the accompanying checks and balances promote efficiency, energy, stability, limited government, control of factions, deliberation, the rule of law, and accountability.... [I]n the absence of any specific textual home or pattern of historical practice or judicial precedent, one could reasonably move from these broad and oftenconflicting purposes to any number of fair conclusions about ... almost any freestanding separation of powers question. ${ }^{152}$

146. Id. at 164 (Kavanaugh, J., dissenting).

147. Free Enter. Fund v. Pub. Co. Accounting Oversight Bd., 537 F.3d 667, 688 (D.C. Cir. 2008) (Kavanaugh, J., dissenting) ("Our constitutional structure is premised... on the notion that... unaccountable power is inconsistent with individual liberty."); PHH II, 881 F.3d at 183 (Kavanaugh, J., dissenting) ("The historical practice of structuring independent agencies as multi-member commissions or boards is the historical practice for a reason: It reflects a deep and abiding concern for safeguarding the individual liberty protected by the Constitution.").

148. PHH II, 881 F.3d at 164 (Kavanaugh, J., dissenting).

149. Id. at 105 (majority opinion).

150. Id. at 165 (Kavanaugh, J., dissenting).

151. Id. at 105 (majority opinion) ("Broad observations about liberty-enhancing effects are not themselves freestanding constitutional limitations.").

152. John F. Manning, The Means of Constitutional Power, 128 HARV. L. REv. 1, 56-57 (2014) ("Hence, Justice Brandeis could fairly write that the purpose of the separation of powers was 'not to avoid friction, but, by means of the inevitable friction incident to the distribution of the governmental powers among three departments, to save the people from autocracy.' Justice Jackson, however, could also write, with no less accuracy, that '[w] hile the Constitution diffuses power the better to secure liberty, it also contemplates that practice will integrate the dispersed powers into a 
If we are to take seriously Judge Kavanaugh's approach to the removal power as a possible constitutional standard, then, it must offer more than a reliance on, as Justice Scalia would put it, "ad hoc, standardless judgment[s]" 153 about individual liberty. Further, Judge Kavanaugh's analysis in $P H H$ leaned heavily on historical precedent (or, rather, a lack thereof) as a basis for invalidating the CFPB's design. ${ }^{154}$ But novelty is not itself a constitutional standard. Historical practice might validate an otherwise questionable practice, ${ }^{155}$ but "mere anomaly or innovation" does not offend the Court's constitutional separation-ofpower principles. ${ }^{156}$

Under Judge Kavanaugh's approach, instead of asking "how much removal of Presidential power is too much," 157 courts must instead ask, how much unconstrained agency power is too much? Agency independence is traditionally viewed relative to the executive, but there is a broad set of indicia of independence. ${ }^{158}$ This Comment articulates a framework for Judge Kavanaugh's approach to the removal power that determines the constitutionality of an agency's unaccountable power in light of (1) the nature and scope of an agency's powers, and (2) the structural restraints imposed on the exercise of those powers. Judge Kavanaugh's approach to the removal power, if adopted by the Supreme Court, would raise serious doubts about the constitutionality of independent agencies, most significantly the SSA. This Comment concludes that Judge Kavanaugh's approach would invalidate the SSA's structure after assessing the cumulative effect of the SSA's structural features, including: (1) the nature and scope of power congressionally conferred upon the SSA; (2) the lack of indirect political safeguards; and (3) the lack of external political control. In short, this Comment argues that if Judge Kavanaugh's approach to the removal power invalidates the

workable government."” (first quoting Myers v. United States, 272 U.S. 52, 293 (1926) (Brandeis, J., dissenting); and then quoting Youngstown Sheet \& Tube Co. v. Sawyer, 343 U.S. 579, 635 (1952) (Jackson, J., concurring))).

153. See Morrison v. Olson, 487 U.S. 654, 711-12 (1988) (Scalia, J., dissenting) (criticizing the majority's holding as, among other things, not providing a clear judicially manageable standard on "how much removal of Presidential power is too much").

154. See PHH II, 881 F.3d at 188 (Kavanaugh, J., dissenting) (expressing concern about the "novel[ty]" of the CFPB's novel single-director structure).

155. See, e.g., Printz v. United States, 521 U.S. 898, 905 (1997) (explaining that the "challenge must be sought in historical understanding and practice" because there is no constitutional text directly on point for the specific question asked in this case).

156. Mistretta v. United States, 488 U.S. 361, 385 (1989) (addressing the constitutionality of the Sentencing Commission's composition).

157. Morrison v. Olson, 487 U.S. 654, 711 (1988) (Scalia, J., dissenting).

158. See Datla \& Revesz, supra note 13, at 773. 
structure of the CFPB, then it necessarily invalidates the structure of the SSA as well.

\section{Judge Kavanaugh's Approach to the Removal Power Invalidates the Social Security Administration's Structure}

Congress adopted the Social Security Act of 1935 in the throes of the Great Depression to provide retirement security for American workers as part of the New Deal. ${ }^{159}$ The SSA is an independent agency responsible for administering Social Security, a social insurance program that provides old age, survivorship, and disability benefits to individuals that qualify by virtue of contributions through the Social Security tax on their earnings or on the basis of need. ${ }^{160}$ In particular, the SSA runs two principal benefits programs: Old-Age, Survivors, and Disability Insurance Benefits (OASDI), ${ }^{161}$ an insurance program, and the needbased Supplemental Security Income for Aged, Blind, and Disabled (SSI). ${ }^{162}$ The SSA started out as an independent agency called the Social Security Board, transitioned to a sub-cabinet agency in 1939, and was subsequently restored to its original status as an independent agency in 1995 by the SSA Independence and Program Improvements Act of 1994. ${ }^{163}$ Like the CFPB and the FHFA, the SSA is headed by a single individual, the Commissioner, rather than a multimember body. ${ }^{164}$ The Commissioner serves a six-year term, during which they may be removed by the President only for cause. ${ }^{165}$

\section{Nature and Scope of Power Congressionally Conferred}

Under Judge Kavanaugh's approach to the removal power, the nature and scope of power congressionally conferred upon an independent

159. For a historical background of the SSA, see Historical Background and Development of Social Security, SOC. SEC. ADMIN., https://www.ssa.gov/history/briefhistory3.html [https://perma.cc/ A5DZ-Z4XM] (last visited Jan. 18, 2020).

160. See SSA Organizational Manual: Chapter S - Social Security Administration, Soc. SEC. ADMIN., https://www.ssa.gov/org/orgOC.htm [https://perma.cc/TR79-U53H] (last visited Jan. 18, 2020).

161. See 42 U.S.C. $\S \S 401-434$ (2012).

162. See id. §§1381-1383f.

163. Social Security History: Organizational History, Soc. SEC. ADMIN., https://www.ssa.gov/ history/orghist.html [https://perma.cc/EHE6-QCAX] (last visited Jan. 18, 2020); Historical Background and Development of Social Security, supra note 159.

164. 42 U.S.C. $\S 902$ (a) (2012).

165. Id. The Commissioner "may be removed from office only pursuant to a finding by the President of neglect of duty or malfeasance in office." Id. § 902(a)(3). 
agency is an important consideration. Courts must examine an agency's structural features collectively to determine the constitutionality of its independence. In Morrison, for instance, the Court found fewer protections for a special independent counsel necessary because the nature and scope of the independent counsel's delegated power was narrow and did not include policymaking or significant administrative authority. ${ }^{166}$

In $\mathrm{PHH}$, Judge Kavanaugh argued that the CFPB could not rely upon the SSA as precedent for its structure. ${ }^{167}$ In distinguishing the SSA from the CFPB, Judge Kavanaugh characterized the nature and scope of power wielded by the SSA as less "core" to Article II than those congressionally conferred upon the CFPB. ${ }^{168}$ Judge Kavanaugh argued the SSA Commissioner "does not possess unilateral authority to bring law enforcement actions against private citizens, which is the core of the executive power."169 The SSA lacks authority to impose fines or penalties on individuals in Social Security benefits cases. ${ }^{170}$ The SSA's authority primarily involves processing claims for benefits and adjudicating eligibility. ${ }^{171}$ While the Commissioner does have limited power to initiate a proceeding to determine whether to impose civil sanctions against individuals who file improper claims, they may do so "only as authorized by the Attorney General," an executive officer directly accountable to the President. ${ }^{172}$

Judge Kavanaugh's effort to distinguish away the SSA on the basis that its Commissioner does not exercise core executive functions is unpersuasive. Judge Kavanaugh is correct insofar as he notes that the SSA does not exercise core executive functions. But neither does the CFPB. The CFPB is no more "an arm or an eye of the executive," than the FTC was in Humphrey's Executor. ${ }^{173}$ In this respect, the CFPB's role is materially indistinguishable from the FTC's role, which involves "filling in and administering the details embodied by th[e] general standard[s]" provided in a statute regulating financial transactions. ${ }^{174}$ Some of the CFPB's functions may "to some degree" be executive in

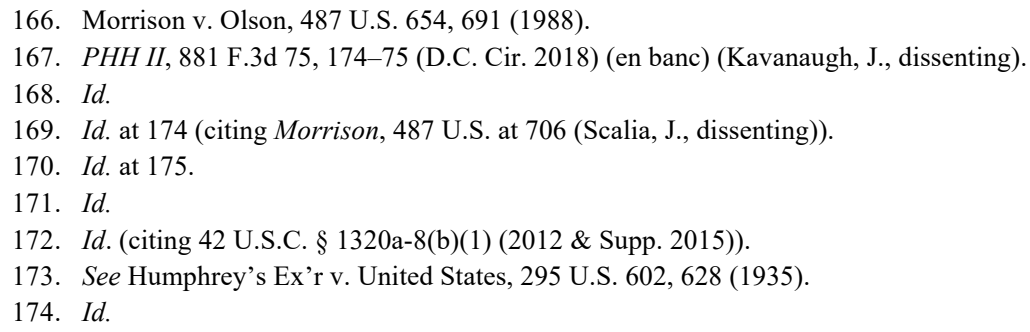


nature, ${ }^{175}$ but they are not "core executive functions." 176 As the en banc $\mathrm{PHH}$ majority put it, "the CFPB is one of a number of federal financial regulators... that have long been permissibly afforded a degree of independence." 177 Because neither the CFPB nor the SSA exercise core executive functions, this is not a factor that distinguishes the two independent agencies.

Further, the scope of the SSA's power is massive. The SSA runs two of the federal government's largest benefit programs, OASDI ${ }^{178}$ and SSI, ${ }^{179}$ handling millions of benefits claims every year. According to the SSA, over sixty-four million Americans received Social Security benefits in 2019. ${ }^{180}$ A report from the AARP Public Policy Institute found that Social Security benefits support over nine million jobs and add about $\$ 1.4$ trillion in output to the American economy. ${ }^{181}$ It is difficult to see how any objective comparison of the SSA and the CFPB could find the latter's power more significant. The SSA not only controls entitlements for millions of Americans but the agency's administration of these benefits also shapes long-term planning for the majority of the country. The SSA's decisions have a great, consequential reach. ${ }^{182}$ In contrast, the CFPB carries out enforcement duties related only to the offering of consumer financial products or services under federal consumer financial laws, ${ }^{183}$ directly affecting only corporate "liberties." 184

\footnotetext{
175. Morrison v. Olson, 487 U.S. 654, 689 n.28 (1988).

176. PHH II, $881 \mathrm{~F} .3 \mathrm{~d}$ at 84 .

177. $I d$.

178. See 42 U.S.C. $\S \S 401-434$ (2012).

179. See id. $\S \S 1381-1383 \mathrm{f}$.

180. Benefits in Current Payment Status, supra note 27.

181. Gary Koenig \& Al Myles, AARP Pub. Pol'y Inst., Social Security's Impact on the NATIONAL ECONOMY 19 (2013).

182. See Soc. Sec. Admin., Fiscal Year 2019 Budget Overview 1 (2019), https://www.ssa.gov/budget/FY19Files/2019BO.pdf [https://perma.cc/A5PD-HUX9] ("The Social Security Administration's programs touch nearly every member of the public at critical junctures in their lives....").

183. See 12 U.S.C. § 5491(a) (2019).

184. Justice Sotomayor made this very observation during oral argument for Seila Law LLC. See Transcript of Oral Argument at 9, Seila Law LLC v. Consumer Fin. Prot. Bureau, No. 19-7 (U.S. argued Mar. 3, 2020) (Sotomayor, J.), https://www.supremecourt.gov/oral_arguments/argument _transcripts/2019/19-7_j4ek.pdf [https://perma.cc/8ML4-VHTQ] ("[T]he Social Security Administration [is] as powerful, if not more powerful, than [the CFPB], because the Social Security Administration affects virtually every American. This agency is limited to the financial market.").
} 


\section{Indirect Presidential Control}

The existence of internal structural mechanisms that constrain agency power and provide the President with indirect political control is another important criteria under Judge Kavanaugh's approach. Such internal structural mechanisms include: (1) a multimember structure; (2) partisan balance requirements; and (3) a superior body within the agency that has the ability to revise, reverse, or alter the decisions of the agency's head.

\section{a. Multimember Structure}

The majority of agencies with statutory removal protection are already headed by multimember bodies. ${ }^{185}$ Under a Judge Kavanaugh removal-power analysis, the multimember structure is a critical indirect political safeguard to constrain independent agency power. Ignoring that the longstanding justification for the multimember leadership structure is insulation from political pressure by the President, ${ }^{186}$ Judge Kavanaugh maintains that the multimember structure prevents the concentration of "all power" in a single, unaccountable individual. ${ }^{187}$ Because independent agencies with a multimember leadership structure do not concentrate "all power" in one person, the multimember structure "reduces the risk of arbitrary decisionmaking and abuse of power." 188 An independent agency exercising "substantial executive authority" therefore requires a multimember structure to "divide and disperse power."189 Under Judge Kavanaugh's approach to the removal power, this is where the problem begins and ends for the SSA. Like the CFPB and the FHFA, a single individual heads the SSA. ${ }^{190}$

185. See Datla \& Revesz, supra note 13, at 793 (listing the CFPB, FHFA, Office of Special Counsel, and SSA as the only agencies that are headed by a single individual with statutory removal protection).

186. See Robert E. Cushman, THE InDEPENDENT REgulatory COMMisSions 153-55 (1941); MARVER H. BERnStein, Regulating Business By InDEPENDENT COMMISSION 107 (1955) ("“I]t was anticipated that such a commission could formulate policy without too much regard for the policies of the administration in power."); see also Transcript of Oral Argument, supra note 184, at 30 (Kagan, J.) ("[I]f a President can get one person on the phone, that's a lot easier than if he has to worry about seven people who are all doing their own thing.... [Y] ou can point at [that one person].").

187. PHH II, 881 F.3d 75, 165 (D.C. Cir. 2018) (en banc) (Kavanaugh, J., dissenting); see also Collins v. Mnuchin, 896 F.3d 640, 667-68 (5th Cir. 2018), aff'd in part, rev'd in part en banc, 938 F.3d 553 (5th Cir. 2019), petition for cert. filed, No. 19-422 (U.S. Sept. 25, 2019).

188. PHH II, 881 F.3d at 165 (Kavanaugh, J., dissenting).

189. Id.

190. See 42 U.S.C. $\S 902(a)(1)$, (4) (2012) ("There shall be in the Administration a 


\section{b. Partisan Balance Requirements}

For Judge Kavanaugh, a statutory bipartisan balance requirement is a critical check on independent agency power. A statutory bipartisan balance requirement is only possible, of course, with a multimember design. ${ }^{191}$ Typically, independent agencies with a multimember structure require political balance, with no more than a bare majority of members from the same political party. ${ }^{192}$ In an era of extreme political polarization, independent agency members are particularly likely to align with the policy preferences of their respective political parties. ${ }^{193} \mathrm{~A}$ bipartisan leadership structure supplies "a built-in monitoring system" for partisan political interests by encouraging a dissent "if the agency goes too far in one direction." 194 That dissent can serve "as a 'fire alarm' that alerts Congress and the public at large that the agency's decision might merit closer scrutiny."195 From Judge Kavanaugh's perspective, there is nobody at the SSA to ring the alarm.

Like the FHFA and CFPB, the SSA lacks a bipartisan balance requirement. Its single Commissioner is necessarily of a single party, the party of the appointing President. ${ }^{196}$ The SSA Commissioner serves a fixed six-year term, an even longer term than the directors of both the CFPB and FHFA. ${ }^{197}$ A SSA Commissioner from the President's opposing party may therefore command the agency for the entirety of the President's term.

\footnotetext{
Commissioner of Social Security .... The Commissioner shall be responsible for the exercise of all powers and the discharge of all duties of the [SSA], and shall have authority and control over all personnel and activities thereof.").

191. PHH II, 881 F.3d at 185 (Kavanaugh, J., dissenting); Collins, 896 F.3d at 668.

192. Marshall J. Breger \& Gary J. Edles, Established by Practice: The Theory and Operation of Independent Federal Agencies, 52 ADMIN. L. REV. 1111, 1138-39 (2000). For instance, the Federal Deposit Insurance Corporation is governed by a five-member body, no more than three of which may be of the same political party. 12 U.S.C. § 1812(a) (2018). Similarly, the Federal Trade Commission, composed of five members, may have no more than three members of the same political party. 15 U.S.C. $\S 41$ (2018). Not all multimember independent agencies are structured this way. The NLRB and the Federal Reserve Board of Governors, for instance, do not require bipartisanship. See 29 U.S.C. § 153(a) (2012) (NLRB); 12 U.S.C. § 242 (2018) (Federal Reserve).

193. See Neal Devins \& David E. Lewis, Not-So Independent Agencies: Party Polarization and the Limits of Institutional Design, 88 B.U. L. REV. 459, 491-92 (2008) (noting that empirical studies of commissioner voting practices and the nomination process support this claim).

194. Rachel E. Barkow, Insulating Agencies: Avoiding Capture Through Institutional Design, 89 TEX. L. REV. 15, 41 (2010) (citing Hugo Hopenhayn \& Susanne Lohmann, Fire Alarm Signals and the Political Oversight of Regulatory Agencies, 12 J.L. ECON. \& ORG. 196, 197-98 (1996)).

195. Id. (citations omitted).

196. See PHH II, 881 F.3d at 148 (Henderson, J., dissenting).

197. 42 U.S.C. $\S 902(a)(3)(2012)$. The CFPB and FHFA directors serve fixed five-year terms. 12 U.S.C. § 5491(c)(1) (2018) (CFPB); id. § 4512(b)(2) (FHFA).
} 


\section{c. Formal Oversight}

The extent to which a politically accountable body has statutory power to revise, reverse, or modify the decision of an agency head is another measure of internal political safeguard. In Free Enterprise Fund, for instance, a problem with the dual-layer removal protections was that the Sarbanes-Oxley Act did not give the SEC "effective power to start, stop, or alter individual [PCAOB] investigations, executive activities typically carried out by officials within the Executive Branch." 198 The PCAOB exercised "substantial executive authority," including investigatory, enforcement, and policymaking functions, left unreviewable by a politically accountable body. ${ }^{199}$ In contrast, the Court in Morrison found the independent counsel at issue had "limited jurisdiction and tenure and lack[ed] policymaking or significant administrative authority." 200 The independent counsel's role was limited to "investigation and, if appropriate, prosecution for certain federal crimes." ${ }^{, 201}$ And that limited jurisdiction was subject to Department of

198. Free Enter. Fund v. Pub. Co. Accounting Oversight Bd., 561 U.S. 477, 504 (2010). Justice Breyer in dissent, however, argued that the SEC has "virtually absolute" control over the PCAOB's investigative and legal functions. Id. at 529 (Breyer, J., dissenting). Justice Breyer noted:

- No Accounting Board rule takes effect unless and until the Commission approves it; The Commission may "abrogat[e], delet[e] or ad[d] to" any rule or any portion of a rule promulgated by the Accounting Board whenever, in the Commission's view, doing so "further[s] the purposes" of the securities and accounting-oversight laws;

- The Commission may review any sanction the Board imposes and "enhance, modify, cancel, reduce, or require the remission of" that sanction if it finds the Board's action not "appropriate";

- The Commission may promulgate rules restricting or directing the Accounting Board's conduct of all inspections and investigations;

- The Commission may itself initiate any investigation or promulgate any rule within the Accounting Board's purview, and may also remove any Accounting Board member who has unreasonably "failed to enforce compliance with" the relevant "rule [s], or any professional standard";

- The Commission may at any time "relieve the Board of any responsibility to enforce compliance with any provision" of the Act, the rules, or professional standards if, in the Commission's view, doing so is in "the public interest."

Id. at 528-29 (alterations in original) (citations omitted) (quoting 15 U.S.C. $§ 7217$ (2018)).

199. Id. at 485,505 .

200. Morrison v. Olson, 487 U.S. 654, 691 (1988).

201. Id. at 671-72 (conceding that "the [Ethics and Government] Act delegates to appellant 'full power and independent authority to exercise all investigative and prosecutorial functions and powers of the Department of Justice," " but emphasizing that this delegation "does not include any authority to formulate policy for the Government or the Executive Branch, nor does it give appellant any administrative duties outside of those necessary to operate her office" (quoting 28 U.S.C. § 594(a) (2018))). 
Justice regulations and policies, a politically accountable body. ${ }^{202}$

In Collins v. Mnuchin, the Fifth Circuit placed significant weight on the absence of a statutory provision requiring formal executive control over the FHFA. ${ }^{203}$ Congress did establish the Federal Housing Finance Oversight Board (FHFOB), but as its title suggests, the FHFOB "exercises purely advisory functions." ${ }^{204}$ Aside from requiring a special meeting of the FHFOB, ${ }^{205}$ the executive branch, through the FHFOB, "can do nothing more than cajole the FHFA into acting." 206 The Fifth Circuit compared the FHFA's FHFOB to the CFPB's FSOC. The court argued that the FSOC allows the President to influence the CFPB's actions through the appointment of a supermajority of FSOC members. ${ }^{207}$ And in contrast to the FHFOB, the FSOC holds a " "powerful' oversight mechanism" over the CFPB because the FSOC may set aside CFPB regulations that put the safety and soundness of the U.S. banking or financial system at risk. ${ }^{208}$

It remains unclear, however, how "powerful" the FSOC's veto mechanism is and how much control the FSOC has over the CFPB in practice. $^{209}$ The Fifth Circuit acknowledged this in a carefully-placed footnote, acknowledging that "whether the FSOC is a 'meaningful substitute check' on the CFPB's actions" is an open question. ${ }^{210}$ The Fifth Circuit quoted a portion of Judge Henderson's $P H H$ dissent that described the FSOC's veto power as so narrow that it is "a testament to

202. Id. at 662 ("[A]n independent counsel 'shall, except where not possible, comply with the written or other established policies of the Department of Justice respecting enforcement of the criminal laws."' (quoting 28 U.S.C. § 594(f))).

203. 896 F.3d 640, 669-70 (5th Cir. 2018), aff'd in part, rev'd in part en banc, 938 F.3d 553 (5th Cir. 2019), petition for cert. filed, No. 19-422 (U.S. Sept. 25, 2019).

204. Id. at 669; 12 U.S.C. $§ 4513 a(a)-(b) ~(2018)$.

205. 12 U.S.C. $\S 4513 \mathrm{a}(\mathrm{d})(2)(2018)$.

206. Collins, 896 F.3d at 669.

207. Id. at 669-70 (quoting PHH II, 881 F.3d 75, 120 (D.C. Cir. 2018) (en banc) (Wilkins, J., concurring)).

208. Id. at 670 (quoting PHH II, 881 F.3d at 120 (Wilkins, J., concurring)).

209. See Randall D. Guynn et al., Fifth Circuit Holds That FHFA Is Unconstitutionally Structured, DAVIS POLK: FINREG (July 18, 2018), https://www.finregreform.com/single-post/2018 /07/18/fifth-circuit-holds-fhfa-unconstitutionally-structured/ [https://perma.cc/78E8-BYN5]. This discussion illustrates one of the ways in which Judge Kavanaugh's approach to the removal power is problematic. As Justice Breyer explained in his Free Enterprise Fund dissent, "[c]ompared to Congress and the President, the Judiciary possesses an inferior understanding of the realities of administration, and the manner in which power, including and most especially political power, operates in context." Free Enter. Fund v. Pub. Co. Accounting Oversight Bd., 561 U.S. 477, 523 (2010) (Breyer, J., dissenting).

210. Collins, 896 F.3d at 670 n.233 (quoting PHH II, 881 F.3d at 159-60 (Henderson, J., dissenting)). 
the CFPB's unaccountable policymaking power."211 Presumably in an attempt to minimize the fact that this distinction between the FHFA and the CFPB - the only real distinction the court identified ${ }^{212}$ - is not much of a distinction after all, the Fifth Circuit closed by deflecting: "This magnifies the concern here: the FHFA lacks any oversight body." 213

The FHFA is not the only independent agency headed by a single individual whose board is largely limited to providing advice. The SSA established the Social Security Advisory Board (SSAB) to "advise the Commissioner on policies related to" Social Security benefits programs. ${ }^{214}$ Like the FHFOB, the SSAB does not possess veto power over the Commissioner's decisions. ${ }^{215}$ Rather, the SSAB's specific functions are mostly limited to "making recommendations" on matters related to the SSA's duties. ${ }^{216}$ The SSA Commissioner is therefore not subject to the control of a politically accountable body within the agency with statutory power to revise, reverse, or modify the decisions of its Commissioner.

\section{External Political Control}

An independent agency's power is also constrained by the President ability to maintain external political control over the agency through: (1) staggered appointments; (2) the ability to appoint and remove agency chairs at will; and (3) the agency's funding structure.

\section{a. Staggered Appointments}

Members of independent agencies with a multimember structure typically serve staggered terms. ${ }^{217}$ Although holdover appointees will remain when administrations change, members of independent agencies often resign when a President of the opposing party takes office. ${ }^{218}$

\footnotetext{
211. Id.

212. See discussion supra notes $115-22$ and accompanying text.

213. Collins, 896 F.3d at 670 n.233.

214. 42 U.S.C. $\S 903(b)(2012)$.

215. See id.

216. Id.

217. See, e.g., 15 U.S.C. $\S 41$ (2018) (FTC, seven-year staggered terms); id. § 78d(a) (SEC, fiveyear staggered terms); 29 U.S.C. § 153(a) (2012) (NLRB, five-year staggered terms).

218. See Terry M. Moe, Regulatory Performance and Presidential Administration, 26 AM. J. POL. SCI. 197, 200 (1982) ("[C]ommission chair[persons] have tended to resign from their commissions (not simply from the chairmanship) upon losing presidential support, bolstering the President's effective power of removal.”); see also Datla \& Revesz, supra note 13, at 821 (noting as an example that "the Chairman of the SEC typically resigns both the chairmanship and the
} 
According to Judge Kavanaugh, "Even apart from that tradition, the staggered terms mean that a President will have ever-increasing influence (through appointments) over an independent agency during the course of that President's term." 219

By virtue of its single-head design, the SSA, under Judge Kavanaugh's approach, provides the President with "zero influence" over the agency through appointment - a "zero [that] remains zero" until the expiration of the Commissioner's term. ${ }^{220}$ Judge Kavanaugh concedes that this reasoning might "be criticized as elementary arithmetical logic," but nevertheless maintains that "some influence exceeds zero influence."221 If the single-head design of the CFPB and the FHFA deprives the President from exerting political control to constrain the agency's power under Kavanaugh's approach, then so does the single-head design of the SSA.

\section{b. Ability to Appoint and Remove Agency Chairs at Will}

In addition to providing indirect political control, Judge Kavanaugh argues that the multimember structure increases presidential influence and oversight through the power to designate agency chairs and to remove chairs from their position as chair at will. ${ }^{222}$ The chair often has some authority over the agency's budget and personnel decisions, sets the agency's agenda, and is generally the agency's "public voice." 223 Because the President cannot remove chairs from their position as agency members, however, this power is limited. ${ }^{224}$ Notwithstanding this

commission seat upon the election of a new President"). But see Devins \& Lewis, supra note 193, at 497 (“[O]pposition-party commissioners serve out most, if not all, of their terms.").

219. PHH II, 881 F.3d 75, 190 (D.C. Cir. 2018) (en banc) (Kavanaugh, J., dissenting).

220. Id. (evaluating the CFPB's structure).

221. Id. (quoting Free Enter. Fund v. Pub. Co. Accounting Oversight Bd., 561 U.S. 477, 501 (2010)).

222. Id. at 166; see also Collins v. Mnuchin, 896 F.3d 640, 667 (5th Cir. 2018), aff'd in part, rev'd in part en banc, 938 F.3d 553 (5th Cir. 2019), petition for cert. filed, No. 19-422 (U.S. Sept. 25, 2019); Paul R. Verkuil, Jawboning Administrative Agencies: Ex Parte Contacts by the White House, 80 CoLUM. L. REV. 943, 955 n.75 (1980) (noting the President appoints the chairs of the FTC, FCC, SEC, and NLRB); Peter L. Strauss, The Place of Agencies in Government: Separation of Powers and the Fourth Branch, 84 CoLuM. L. REV. 573, 590-91 (1984) (arguing the President can influence the priorities and policy direction of independent agencies by designating a chair).

223. Datla \& Revesz, supra note 13, at 819; see also Daniel E. Ho, Measuring Agency Preferences: Experts, Voting, and the Power of Chairs, 59 DEPAUL L. REV. 333, 337 (2010) ("[V]ote-based studies of regulatory behavior may fail to capture essential parts of agency behavior, namely, the agenda-setting power of agency chairs.").

224. Ho, supra note 223 , at 338 (discussing a study that demonstrates agency chairs typically resign when the President removes them from the chair position, providing the President with a new appointment (citing David C. Nixon \& Thomas M. Grayson, Chairmen and the Independence of 
limitation, Kirti Datla and Professor Richard Revesz argue that "[t]he ability of the President to retain policy influence through the selection of the chair is important because ... the "chair of a [multimember] agency is ordinarily its most dominant figure," and "[a]n appointed chair will align with the President." 225 The ability to appoint a chair, while arguably limited in scope, gives the President some external control.

Headed by a single individual, the SSA has no chair. The inability to designate and remove at will chairs from the chair position was a significant factor to both Judge Kavanaugh in $P H H$ and the Fifth Circuit Collins panel in finding the single-head structure unconstitutional. ${ }^{226}$ Because of the single-head structure, a President "may be stuck for years" with an SSA Commissioner, a CFPB Director, or a FHFA Director appointed by a previous President who "vehemently opposes the current President's agenda."227 For Judge Kavanaugh, this "additional diminution of Presidential authority exacerbates the Article II problem." 228

\section{c. Agency Funding Sources}

Although largely overlooked, ${ }^{229}$ an agency's funding structure implicates both the President and Congress's political control. ${ }^{230}$ In

Independent Regulatory Commissions 12 (Mar. 2003) (unpublished manuscript))).

225. Datla \& Revesz, supra note 13, at 819 (quoting Breger \& Edles, supra note 192, at 1164); see also Glen O. Robinson, Independent Agencies: Form and Substance in Executive Prerogative, 1988 DUKE L.J. 238, 245 n.24 (1988) ("From personal experience [as a former FCC Commissioner] I can report that the FCC's chairman and a handful of staff - usually selected by the chair - can and usually do exercise nearly total control over that agency's basic policy agenda.").

226. See PHH II, 881 F.3d at 188 (Kavanaugh, J., dissenting) ("The single-Director structure of the CFPB ... diminishes the President's power to exercise influence over the CFPB, as compared to the President's power to exercise influence over traditional multi-member independent agencies."); Collins v. Mnuchin, 896 F.3d 640, 667-68 (5th Cir. 2018) ("In multi-member agencies whose leaders are protected from at-will removal, the President can still influence the agency through the power "to designate the chairs of the agencies and to remove chairs at will from the chair position." (quoting PHH II, $881 \mathrm{~F} .3 \mathrm{~d}$ at 166 (Kavanaugh, J., dissenting)), aff'd in part, rev'd in part en banc, 938 F.3d 553 (5th Cir. 2019), petition for cert. filed, No. 19-422 (U.S. Sept. 25, 2019).

227. PHH II, 881 F.3d at 167 (Kavanaugh, J., dissenting)

228. Id. at 188 .

229. Steven A. Ramirez, Depoliticizing Financial Regulation, 41 WM. \& MARY L. REV. 503, 517 (2000) (expressing "surpris[e]" that most regulatory reform proposals do not focus on agency financing). Judge Kavanaugh's $P H H$ panel opinion largely neglected the CFPB's funding structure as an indicium of independence, burying a brief mention of Congress's power of the purse in a footnote: "The CFPB's exemption from the ordinary appropriations process is at most just 'extra icing on' an unconstitutional 'cake already frosted." PHH I, 839 F.3d 1, 36 n.16 (D.C. Cir. 2016) (quoting Yates v. United States, 574 U.S. 528, 557 (2015) (Kagan, J., dissenting)).

230. See Henry B. Hogue et al., Cong. Research SerV., R43391, Independence of Federal Financial Regulators: Structure, Funding, AND Other IsSues 3 (2017), 
Professor Rachel Barkow's words, to "locate power in Washington (and just about any place else), you must follow the money."231 If an agency's budget requests must be vetted and approved by the Office of Management and Budget (OMB), the President has "significant input into the agency's size, scope, and activities," even if the agency head is removable only for cause. ${ }^{232}$ Likewise, if an agency's budget is set through congressional authorization and appropriations, partisan political power can exert influence over the agency. ${ }^{233}$ Funding an agency outside of the appropriations process therefore further insulates the agency from partisan political influence. ${ }^{234}$ As Justice Breyer recognized, "who controls the agency's budget requests and funding... affect[s] the

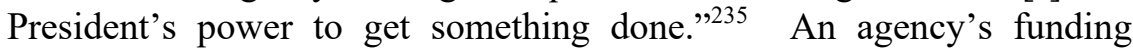
structure thus relates to presidential influence over independent agencies.

Benefit payments for SSA programs are part of the federal government's mandatory spending because the SSA is statutorily required to pay them. ${ }^{236}$ The benefits the SSA programs pay are therefore placed outside the annual appropriations process. ${ }^{237}$ Congress does, however, control funding for the SSA's administrative budget, arguably providing Congress with some influence of the agency. ${ }^{238}$ But the annual budget for the SSA prepared by the Commissioner is submitted to Congress by the President "without revision,", 339 depriving the President any leverage over the SSA's activities. ${ }^{240}$ The SSA's

\footnotetext{
https://fas.org/sgp/crs/misc/R43391.pdf [https://perma.cc/M6RQ-TQPU] (noting that funding an agency outside of the appropriations process "shield[s] an agency from congressional control and presidential direction," which "might further insulate the agency from partisan political influence"); see also Barkow, supra note 194, at 43 ("[T] he power of the purse is one of the key ways in which democratic accountability is served." (citation omitted)).

231. Barkow, supra note 194, at 42.

232. HogUe ET AL., supra note 230, at 19.

233. See Richard F. Fenno, JR., The Power of the Purse: Appropriations Politics in CONGRESS 291 (1966) ("Once the Committee's ability to hurt it is recognized, the most obvious way for the agency to ensure a favorable kind of relationship with the Committee is simply to do ... what the Committee tells it to do."); S. COMM. ON GOv'T Operations, Study ON Federal REgUlation: CONGRESSIONAL OVERSight OF REgUlATORY AGENCIES, S. DOC. NO. 95-26, at 42 (1st Sess. 1977) ("The appropriations process is the most potent form of Congressional oversight....").

234. PHH II, 881 F.3d 75, 147 (D.C. Cir. 2018) (en banc) (Henderson, J., dissenting).

235. Free Enter. Fund v. Pub. Co. Accounting Oversight Bd., 561 U.S. 477, 524 (2010) (Breyer, J., dissenting).

236. See Mindy R. LeVit et Al., Cong. ReSEarch SerV., RL33074, Mandatory SPEnding SINCE 1962, at 1 (2015), https://fas.org/sgp/crs/misc/RL33074.pdf [https://perma.cc/CB5R-PE9A].

237. See 42 U.S.C. § 904(b) (2012).

238. See id.

239. Id. § 904(b)(1)(A).

240. See Collins v. Mnuchin, 896 F.3d 640, 669 (5th Cir. 2018), aff'd in part, rev'd in part en
} 
funding structure therefore does not distinguish the agency from the FHFA or the CFPB. In fact, none of the factors identified in this Comment distinguish the SSA's structure from the structure of the FHFA or the CFPB for purposes of Judge Kavanaugh's approach to the removal power.

\section{CONCLUSION}

Judge Kavanaugh's approach to the presidential removal power in $P H H$, if adopted by the Supreme Court, would raise serious questions about the constitutionality of the SSA's structure because there is no meaningful distinction between the SSA and the CFPB (or the FHFA, for that matter). First, like the CFPB and the FHFA, the SSA is led by a single individual: the SSA Commissioner. The President may only remove the SSA Commissioner for cause. Second, the SSA lacks a bipartisan balance requirement, removing a critical check on agency power. Third, the SSA is not subject to oversight by a politically accountable body because the SSAB performs an advisory oversight role. Fourth, the SSA funding structure prevents presidential influence. Thus, "[a]11 of that massive power" is "lodged in one person"- the SSA Commissioner - "who is not supervised, directed, or removable at will by the President." 241 From Judge Kavanaugh's perspective, this excessive insulation from presidential control violates separation of powers. Judge Kavanaugh's solution: sever the for-cause removal provision. ${ }^{242}$

But doubt about the SSA's constitutional status is just one specific implication. Judge Kavanaugh's approach also lays the groundwork for invalidating all independent agencies, reviving a separation of powers that sharply constrains the modern administrative state. If the Supreme Court adopts Judge Kavanaugh's approach, it may become difficult to draw the lines in a way that preserves many longstanding administrative structures.

Judge Kavanaugh assumes that presidential control over agencies would increase accountability and help preserve individual freedom. It is worth asking whether conservative judges would be so eager to expand presidential control if President Barrack Obama were still in office.

\footnotetext{
banc, 938 F.3d 553 (5th Cir. 2019), petition for cert. filed, No. 19-422 (U.S. Sept. 25, 2019); see also Barkow, supra note 194, at 44 ("With independent funding, the agency is insulated from ... the President." (citation omitted)).

241. See PHH II, 881 F.3d 75, 171 (D.C. Cir. 2018) (en banc) (Kavanaugh, J., dissenting).

242. See PHH I, 839 F.3d 1, 38-39 (D.C. Cir. 2016).
} 
Given our increasingly polarized political system, the notion that the President's control over agencies makes them politically accountable seems quaint. As Professor Gillian Metzger explained, aggrandizement of executive power in response to fears of unaccountable agency power "may simply worsen the problem, adding the President's popular authority and political leadership to the mix of executive, legislative, and adjudicatory powers agencies wield on their own." 243

243. Gillian E. Metzger, Foreword: 1930s Redux: The Administrative State Under Siege, 131 HARV. L. REV. 1, 37 (2017). 